\title{
Factors That Influence Investments in The Indonesia Stock Exchange to Improve Understanding of Capital Market Subjects Study on Unimed Campus Communities
}

\author{
Roza Thohiri ${ }^{1 *}$, Revita Yuni ${ }^{2}$, Pebri Hastuti ${ }^{3}$, Arwansyah $^{4}$ \\ ${ }^{1234}$ Department of Economic Education, Universitas Negeri Medan, Indonesia \\ *rozatho@unimed.ac.id
}

\begin{abstract}
Inflation occurring in Indonesia tends to not be able to cover investment in the form of savings. The capital market in Indonesia is currently promoting investment in shares with the slogan "let's save shares", which at this time the returns continue to improve. This research was conducted to identify the characteristics of stock investors in the Indonesian stock exchange, analyze the decision making process of stock investors to choose stocks in the Indonesian stock exchange and find out what factors influence investors in investing in the capital market and to be an additional understanding in capital market subjects. This research was conducted at the faculty of economics UNIMED. This research is a qualitative study using primary data and secondary data. This study uses a simple random sampling method with the slovin's formula and the sample is 316 respondents. The data analysis technique used is the validity and reliability of the questionnaire given to respondents, descriptive analysis and factor analysis. From the results of the study found that the validity and reliability in this study are valid and reliable. In the decision-making stage of stock purchase, it is obtained the introduction of problems with sources of income as the main goal to get capital gains and dividends. Most information searches come from the internet with information searching time around 1-2 days. In evaluating alternatives in making purchases, it turns out stock is the main choice with the main consideration being the profit potential. In determining the purchase decision all respondents have planned well and themselves have the most influence with the decision making time ranging from 2-7 days. Post-purchase behavior respondents were satisfied with their decision and the waiting time to get benefits ranged from 3-4 weeks. This research shows, there are 4 factors that influence investors in buying and selling shares on the Indonesia Stock Exchange, namely information factors, preferred stock factors, market activity factors and risk limiting factors. The most influential dominant factor is the information factor of 46.52 percent.
\end{abstract}

Keywords: Capital Market, Investors, Education, Factor Analysis

\section{Introduction}

Inflation is a financial threat faced by every individual. Individuals who do not prepare their financial planning have great potential to lose money in the future. Inflation can be interpreted as a decrease in the purchasing power of money for goods or services [1]. Money with the 
same nominal over time can't afford to buy goods of the same value or the same. Indonesia's annual inflation data for the past five years can be seen in the figure below.

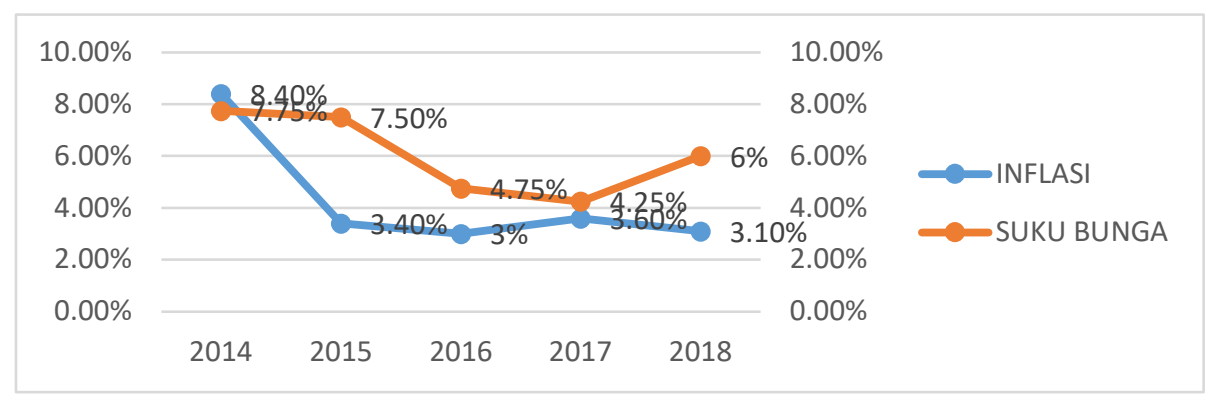

Fig 1. Data on annual inflation and bank interest rates in Indonesia

Indonesia's annual inflation tends to fluctuate. During the period 2014 to 2018 Indonesia's inflation rate averaged 4.30 percent. After dropping to its lowest point in five years at 3 percent Year on Year in 2016, Indonesia's inflation increased again at 3.6 percent in 2017. Many ways can be done to deal with inflation. It can be in the form of saving money in a bank by expecting a return in the form of interest rates or investing with opportunities for acquisition greater than the amount of inflation. When compared to the amount of the return, between saving at the bank with investment, the investment is worthy of choice because savings have an average interest rate of 6.05 percent or only a difference of 1.75 percent of Indonesia's average inflation. While investment products have an average return of 8.11 percent in the last 3 years.

According to Haming and Basalamah [2], investment can be interpreted as an activity to invest a number of capital or money carried out at this time in the hope of obtaining profits or returns from capital within a certain period of time. Each type of investment has its own characteristics related to the returns obtained, namely the level of investment risk, the ideal investment period, the ease of withdrawing investment, and the amount of capital needed. Investment can be made in various instruments and places. One of them is investing in the capital market or capital market. The capital market acts as a liaison between investors and companies or government institutions through trading long-term instruments such as stocks, bonds, mutual funds and so forth. The purpose of investors in investing is to get a return on the amount of capital invested. Different investment products also have different returns. Data on the return on investment products can be seen in the figure below.

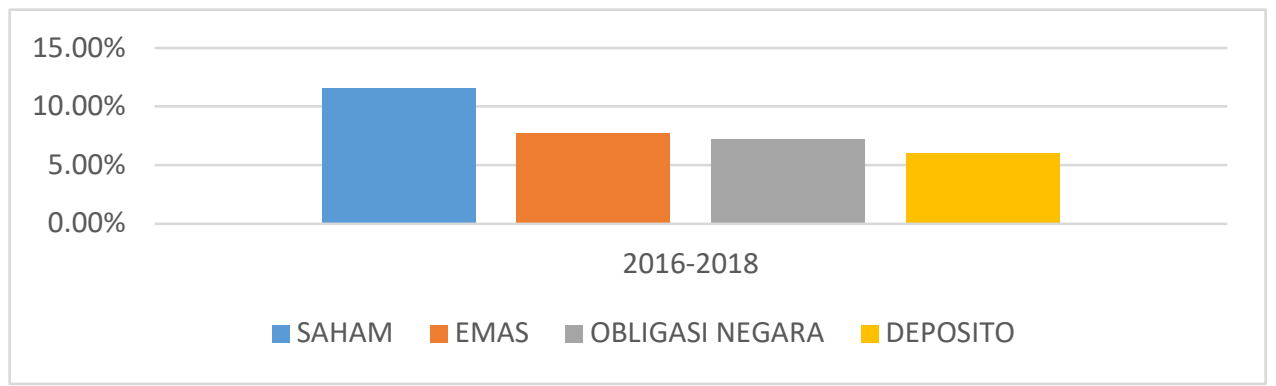

Fig 2. Return on Investment Products 
Capital market investment products in the form of shares have the highest rate of return compared to other products with an average growth of 11.59 percent per year. In addition to the high rate of return, stocks are also an investment that is easily disbursed by investors. Choosing a stock as an investment must consider many factors, if one chooses a stock, it is not the profit gained but the loss. Some of these factors include the issuer, the time of purchase and sale, the company's financial statements, the history of stock movements, global market conditions, government policies and other factors that can be taken into consideration during the decision making process.

According to Cholidia [3] the decision-making process in choosing stocks produces two types of investors, namely investors who consider rationally and investors who emphasize psychological aspects such as experience and trust in other people's references. Decisionmaking that only based on irrational considerations will produce results that are not optimal, of course, this is detrimental to investors.

Investor growth in the Indonesian capital market is considered quite good. However, when compared to other countries, the public interest in Indonesia for investment is still quite low, namely only around $0.15 \%$ of Indonesia's population, while the population of Malaysia is around $15 \%$, Singapore $30 \%$ and Australia 30\%. Based on data from the Financial Services Authority in Indonesia, the number of securities accounts is still very small, which is less than 600,000 accounts compared to Thailand that has reached 25 million accounts. PT BEI (BEI) recorded the number of investors through the Single Investor Identification (SID) has reached 494 thousand as of August 22, 2016. The number of investors has increased every month. As of August 10, 2016, IDX released data on the number of Indonesian companies that successfully went public, amounting to 517. The number of new companies could be one of the factors driving the number of investors, especially in stock investments in the capital market. However, the large number of companies alone will not significantly influence the growth of the number of investors if the awareness of investment from the community itself is still low. OJK in 2013 conducted a survey regarding the level of literacy in financial comprehension. The survey results obtained by the FSA show that only about 21.8 percent of the 9,000 respondents in all of Indonesia, meaning that only a small number of Indonesians understand financial. Even though the number of investors in the capital market is increasing every year, based on data released by the Indonesian Central Securities Depository (KSEI), it is reported that based on ownership, the total assets of shares until July 29, 2016 are still dominated by foreign investors.

Indonesia is a developing country where its financial orientation is short-term or in the category of saving society. When compared with developed countries, the orientation is more in the long term or in the category of investing society. Awareness of their financial management is so great that they are able to set aside 30 percent of their income for investment. Therefore, intensive and sustained public education is needed to change the society from a saving society to an investing society. Education that is carried out in stages is expected to be able to build community motivation to move from saving to investing.

Education about the capital market to the public is important because it is useful to increase the number of interested parties to invest in the capital market [4]. Therefore, the government through the IDX launched a campaign movement program called "Let's Save Stocks" in order to increase the number of investors in the Indonesian capital market. This campaign aims to motivate, educate and develop the capital market industry, as well as adding new investors who target young people, such as students, students, and young employees. Existing investments have various types. One form of investment that is popular and attractive nowadays is investment in the form of shares. Shares are proof of ownership of a company in 
which the owner is also a shareholder [5]. Based on a survey conducted by IDX, Nielsen, and the University of Indonesia, it is known that young people have great potential to become stock investors. From the results of these studies it turns out that ownership of shares began to become part of people's lifestyles [6]. The trend in buying luxury and branded goods to be used as investment instruments began to recede. Lately, the public has again looked at investments in the capital market through share saving. This is inseparable from the campaign movement carried out by IDX. Unimed campus community is also a target of the IDX as investors and prospective investors, information to add insight and confidence in understanding capital market courses will also increase motivation in investing and on the background described above. The formulation of the problem in this research is what factors influence the Unimed campus community in investing in the IDX. The scope of this research is the financial study of the factors that influence investors in investing in the IDX and the respondents involved are lecturers, employees and students who have taken or are currently taking capital market courses.

This study aims to identify the characteristics of stock investors on the IDX, analyze the investor decision-making process and see what factors influence the unimed campus community in investing in the capital market. The benefit of this research is that it can provide information to investors who will invest in the capital market, so that investors can obtain maximum investment returns and can increase understanding of investor behavior in stock investment decision-making and can provide additional information and data for research with similar themes.

\section{Purchase Decision Process}

Consumer decision making includes all the processes that consumers go through in identifying problems, finding solutions, evaluating alternatives, and choosing between their purchasing choices. According to Kotler and Keller [7], there are five stages of the purchase decision process, namely problem recognition, information search, alternative evaluation, purchase decision, and post-purchase behavior. We can describe the decision process as follows:

a. Problem Recognition, the buying process starts when the buyer is aware of a problem or need that is triggered by internal and external stimuli. With internal stimulation one of one's normal needs rises to the maximum level and becomes an impulse; or needs can arise due to external stimuli.

b. Information Search, we can distinguish between two levels of involvement with search. This lower search state is called sharp attention. At this level a person just becomes more receptive to information about a product. At the next level, one can enter active information search by looking for reading material, calling friends, doing online activities, and visiting stores to learn about the product. There are main sources of information where consumers are divided into four groups: personal (family, friends, neighbors, colleagues), commercial (advertisements, websites, sales people, distributors, packaging, display), public (mass media, consumer rating organizations), and experimental (handling, checking, product use).

c. Alternative Evaluation, the basic concept that helps us understand the evaluation process that is consumers are trying to satisfy a need, consumers are looking for certain benefits from product solutions and consumers see each product as a group of attributes with various abilities to deliver the benefits needed to satisfy these needs. Consumers will pay the greatest attention to the attributes that deliver benefits that meet needs. 
d. Purchasing Decisions, in the evaluation phase, consumers form inter-brand preferences in a collection of choices. Consumers might also form an intention to buy the most preferred brand. In carrying out the purchase intention, consumers can form five sub-decisions namely brand, supplier, quantity, time, and payment method.

e. Post Purchase Behavior, after a purchase consumers may experience conflict due to seeing certain worrying features or hearing pleasant things about other brands and be alert to information that supports their decision.

\section{Factors That Influence Investors in Investing}

Investment can be interpreted as an activity to invest a number of capital or money carried out at this time in the hope of obtaining profits or returns from that capital within a certain time period. This statement is in line with the opinion of Tandelilin [8] commitment to a number of funds or other resources made at this time with the aim of obtaining future benefits. Broadly speaking, investment is divided into two types, namely real investment and financial investment. Real investment can be defined as investment with real or real objects, for example investment in property, gold, land, trading, and so on. While financial investment is an investment in financial assets for example stocks, deposits, bonds, and so forth. The psychology of a trader greatly influences the level of success in investing, because it affects the decisions taken when trading stocks. According to Wira [9] the basic behavior of traders when trading shares is divided into two, namely seeking pleasure and avoiding suffering/loss. When in a state of loss the trader will make several alternative choices including fighting, that is, the trader is confident in his analysis. Then the second alternative is to survive or accept the situation, and the last is to leave a loss or cut loss. There are many factors that can influence stock investment decisions on the IDX. According to Septyanto [10] there are several factors that influence investment in the capital market, both internal company factors in the form of information, risks and returns, corporate policies, and external factors in the form of world market conditions, as well as issues or rumors.

Information. Information has a significant influence to shape an investor's perception in making decisions. Scoot [7] states that accounting information contains information if it helps inveso revise the initial beliefs of shares in the decision making process of buying or selling shares. Information limitations make a decision difficult and affect investors' decisions to choose the offered stock. Product information can be received by investors in various forms such as financial statements, fundamental and technical analysis of shares, business performance of listed companies, future business prospects and recommendations from stock analysts.

Risk and Return. Risk is an opportunity for failure to get a yield in accordance with estimates in an investment and according to Tandelilin [8] risk is the possibility of the difference between the actual return received and the expected return. Risk has a close relationship with the rate of return and these two things can not be separated so that it affects the investment style of a trader. Broadly speaking, there are two strategies that are commonly used by investors in buying and selling shares related to this, namely the stock investment strategy and stock trading May 2017. The stock investment strategy tends to have a low risk because this strategy can reduce the risk of price fluctuations by investing in a stock in the long run. While the stock trading strategy is to buy and sell shares in the short term and focus on the profits derived from the difference between the buying and selling prices, this strategy has a higher risk than the stock investment strategy because it utilizes fluctuations in stock prices. The 
close relationship between risk and profit causes risk and return to be factors that investors consider in investing.

Corporate Policy. Corporate policy is an initiative taken by a company that can have an impact on investor share ownership or the price of the stock itself. Some corporate actions commonly carried out by issuers are buyback and right issue. Buyback is a policy to repurchase shares outstanding in the public by an issuer to increase its share ownership and reduce the number of shares outstanding in the public. While the right issue is a policy to increase the number of shares outstanding in the public with the aim of obtaining additional funds for the issuer.

Investor World Market Conditions. Investors who invest in IDX do not only come from domestic, foreign investors also participate in stock trading on the IDX. This influx of foreign investors also influences the investment strategy of domestic investors by following the activities of foreign investors in buying or selling a stock. This results when foreign investors release their shares, domestic investors join in so that it can cause the index to fall even sharper. Foreign investors invest their capital in exchanges throughout the world so that the exchanges in the world have global links. The events and dynamics of stock prices between one stock exchange with another exchanged influence, especially with exchanges from neighboring countries such as crashes that occur in the Singapore exchange will have an impact on the Taiwan, Hong Kong, Japan and Indonesia stock exchanges.

Rumors or Issues. The strategy of "buy on rumors, sell on news" is mostly carried out by investors in the capital market. Investors have an expectation of getting an abnormal return by buying shares before they become news [11]. In addition to the chance of abnormal returns, the strategy also carries a higher risk. Risks that arise related to changes in patterns of stock price volatility because rumors must be validated before they become information [12].

\section{Research Methods}

\subsection{Place and Type of Research}

The study was conducted at Unimed using questionnaire sheets filled out by investors or potential investors. Types and sources of data used are primary and secondary data. This type of research is quantitative research. The research flowchart illustrates what will be done on the fishbone diagram below:

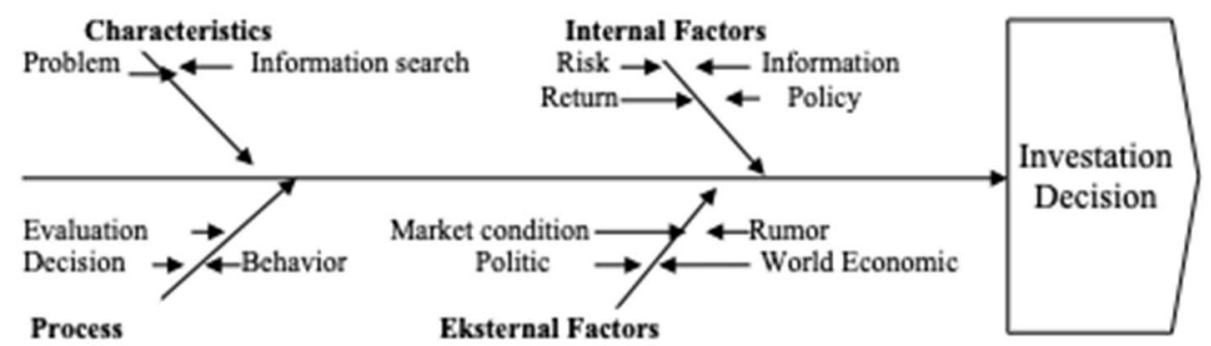

Fig 5. Fishbone Diagram 


\subsection{Data Analysis Technique}

The population in this study is the unimed campus community residing in the faculty of economics, including the population are lecturers, employees and students who have taken or are currently taking capital market courses totaling approximately 1,500 people. The sampling method used is the probability sampling method that is random sampling using simple random sampling. The number of respondents needed in this study was determined by the Slovin formula and the sample in this study was 316 respondents with an error rate of five percent. Validity testing is done using SPSS Statistics software with the technique used Pearson Product Moment. The reliability test used in this study was the Cronbach's Alpha technique. Descriptive statistics are used to describe or give an idea of the object under study through sample data. Factor analysis according to Ghozali [13] is an analysis which aims to define the structure of a data matrix and analyze the structure of interrelationships (correlation) between a large number of variables (test scores, test items, questionnaire answers) by defining a set of variables or dimensions and often called a factor or component). The factor analysis used is principal component analysis (PCA) and common factor analysis which is often called principal axis factoring.

\section{Results and Discussion}

\subsection{Characteristics of Respondents}

Characteristics of respondents in this study can be distinguished by sex, age, last education, occupation and investment duration. Characteristics of respondents can be seen in the table below:

\begin{tabular}{|c|c|c|c|}
\hline No & Characteristics & Sum & Percentage (\%) \\
\hline \multirow[t]{3}{*}{1} & \multicolumn{3}{|c|}{ Sex } \\
\hline & Man & 161 & 50,9 \\
\hline & Woman & 155 & 49,1 \\
\hline \multirow[t]{8}{*}{2} & \multicolumn{3}{|c|}{ Age } \\
\hline & $17-25$ Years & 275 & 87 \\
\hline & $26-30$ Years & 6 & 1,9 \\
\hline & $31-35$ Years & 6 & 1,9 \\
\hline & $36-40$ Years & 17 & 5,4 \\
\hline & $41-45$ Years & 1 & 0,3 \\
\hline & $46-50$ Years & 6 & 1,9 \\
\hline & 50 Years and up & 5 & 1,6 \\
\hline \multirow[t]{6}{*}{3} & \multicolumn{3}{|c|}{ Education } \\
\hline & SMA/SMK & 269 & 85,1 \\
\hline & D3 & 1 & 0,3 \\
\hline & S1 & 5 & 1,6 \\
\hline & S2 & 33 & 10,4 \\
\hline & S3 & 8 & 2,5 \\
\hline \multirow[t]{4}{*}{4} & \multicolumn{3}{|c|}{ Job } \\
\hline & Mahasiswa & 269 & 85,1 \\
\hline & PNS & 41 & 13 \\
\hline & Wiraswasta & 6 & 1,9 \\
\hline 5 & \multicolumn{3}{|c|}{ Long Invest } \\
\hline
\end{tabular}




\begin{tabular}{lcc}
\hline Less 1 Years & 157 & 49,7 \\
\hline $1-5$ Years & 141 & 44,6 \\
\hline $6-10$ Years & 10 & 3,2 \\
\hline $11-15$ Years & 3 & 0,9 \\
\hline $16-20$ Years & 3 & 0,9 \\
\hline 20 Years and up & 2 & 0,6 \\
\hline
\end{tabular}

Based on the table it can be seen that respondents by sex, more respondents with male sex 50.9 percent compared with women 49.1 percent. This shows that the interest of men to invest shares in the IDX is quite large. Based on the age of more respondents in the age range 17 to 25 years 87 percent. If seen based on the last education of respondents with the most recent high school / vocational education dominates with the number of 85.1 percent, based on the work of respondents with jobs as students more with a number of 85 percent then followed by respondents with jobs as civil servants by 13 percent. Based on the length of investment in the capital market, most respondents have invested in a span of less than 1 year on the IDX with 157 respondents followed by 1-5 years as many as 141 people.

\subsection{Validity and Reliability}

The validity test results state that all items declared valid, because the value of $r$ count is greater than the value of $r$ table. The average value of $r$ count is in the range of $0.437-0.800$ which is greater than the value of $r$ table of 0.1104 . Based on statistical tests obtained Cronbach's Alpha value of 0.940 which is greater than 0.60 , the statement in this study can be stated reliably.

\subsection{Descriptive Analysis of Decision Making}

Based on the theory according to Kotler and Keller [7] there are five stages of the purchase decision process, namely problem recognition, information search, alternative evaluation, purchase decision, and post-purchase behavior. The results of the study can be seen in the table below:

Table 2. Stock Buying Decision Process

\begin{tabular}{|c|c|c|c|}
\hline No & Decision Making Stage & Process & $\begin{array}{c}\text { Percentage } \\
(\%)\end{array}$ \\
\hline \multirow[t]{10}{*}{1} & \multirow[t]{10}{*}{ Problem Recognition } & 1.Investment Objectives & \\
\hline & & a.Source of Income & $42 \%$ \\
\hline & & b.Instructional Media & $35 \%$ \\
\hline & & c.Inflation Solution & $18 \%$ \\
\hline & & d.Inheritance and Others & $5 \%$ \\
\hline & & 2.Investment Benefits & \\
\hline & & a.Get CG and Dividends & $40,8 \%$ \\
\hline & & b.Get Dividends & $38,3 \%$ \\
\hline & & c.Get Capital Gain & $19,3 \%$ \\
\hline & & d.Others & $1,6 \%$ \\
\hline \multirow[t]{7}{*}{2} & \multirow[t]{7}{*}{ Information Search } & 1.Information Source & \\
\hline & & a.Internet & $56 \%$ \\
\hline & & b.Seminar/Workshop & $18,4 \%$ \\
\hline & & c.University & $13,6 \%$ \\
\hline & & d.Friends, Family, Media, Analyst & $11,9 \%$ \\
\hline & & 2.Information Search Time & \\
\hline & & a.1-2 Days & $63,9 \%$ \\
\hline
\end{tabular}




\begin{tabular}{|c|c|c|c|}
\hline No & Decision Making Stage & Process & $\begin{array}{c}\text { Percentage } \\
(\%)\end{array}$ \\
\hline & & b.4-6 Hours & $13,6 \%$ \\
\hline & & c.2-7 Days & $12,3 \%$ \\
\hline & & d.Others & $10,2 \%$ \\
\hline \multirow[t]{8}{*}{3} & \multirow[t]{8}{*}{ Alternative Evaluation } & 1.Choosing Stock Considerations & \\
\hline & & a.Potential Benefits & $43,7 \%$ \\
\hline & & b.Stock Price & $24,7 \%$ \\
\hline & & c.Main Business of the Company & $10,1 \%$ \\
\hline & & d.Others & $21,5 \%$ \\
\hline & & 2.Investment Options Other Than Stocks & \\
\hline & & a.Yes & $99 \%$ \\
\hline & & b.No & $1 \%$ \\
\hline \multirow[t]{12}{*}{4} & \multirow[t]{12}{*}{ Purchasing Decisions } & 1.How to Get Decisions & \\
\hline & & a.Planned & $100 \%$ \\
\hline & & 2.Decision Infender & \\
\hline & & a.Self & $75,3 \%$ \\
\hline & & b.Stock Analyst & $10,1 \%$ \\
\hline & & c.Family & $8,1 \%$ \\
\hline & & d.Friends, Web and Others & $6,4 \%$ \\
\hline & & 3.Time of Decision Making & \\
\hline & & a.2-7 Days & $64,6 \%$ \\
\hline & & b.1-2 Days & $13,3 \%$ \\
\hline & & c. $2-4$ Weeks & $10,1 \%$ \\
\hline & & d.Others & $12 \%$ \\
\hline \multirow[t]{10}{*}{5} & \multirow[t]{10}{*}{ Post Purchase Behavior } & 1. Time to get profit & \\
\hline & & a.3-4 Weeks & $36,4 \%$ \\
\hline & & b.Less 1 Weeks & $32 \%$ \\
\hline & & c.1-2 Weeks & $31 \%$ \\
\hline & & d.Others & $0,6 \%$ \\
\hline & & 2. Satisfaction Level & \\
\hline & & a.Satisfied & $56,3 \%$ \\
\hline & & b.Very Satisfied & $34,2 \%$ \\
\hline & & c.Quite Satisfied & $8,5 \%$ \\
\hline & & d.Less Satisfied & $1 \%$ \\
\hline
\end{tabular}

Based on the above table, it can be seen, that the respondents in this research when making the process of making a decision to buy and sell shares, in the introduction stage of the problem of choosing a source of income as the main goal of investing by 42 percent, followed by the media for learning financial products by 35 percent. The expected benefit is getting capital gains and dividends at the same time with a percentage of 40.8 percent and followed by those who only expect a dividend of 38.3 percent. Evaluating the alternative, shares remain the main choice with a percentage of 99 percent and consideration in choosing shares because of the potential profit of 43.7 percent and followed by a share price of 24.7 percent. In the decision making process, respondents are 100 percent planned, and the most influential thing in making decisions is self by 75.3 percent then by stock analysts by 10.1 percent. Postpurchase behaviour of respondents as much as 56.3 percent were satisfied, and as many as 34.2 percent felt very satisfied, the time needed to get a profit of 36.4 percent answered for 3-4 weeks, while less than 1 week was 32 percent. 


\subsection{Factor Analysis}

In this study there are five factors used for factor analysis, namely information factors, risks and returns, corporate policies, world markets, and rumors or issues. This factor has 21 variable elements, namely, financial statements, charts of price movements, issuer's performance, issuer's business prospects, stock analyst recommendations, capital gains and / or dividends, stock support and resistance, bluechip shares, fried stocks, $-2 \%$ risk of losses, $8 \%$ stop loss, right issue, buyback, stock split, GMS, dividend distribution, net foreign buy, net foreign sell, good rumors, and bad rumors.

The first step in factor analysis is to look at the value of the Kaiser-Mayer Olkinmaure of sampling adequacy (KMO). This KMO value is used to determine whether the indicator is suitable to be used. The KMO value can be said to meet the criteria if it is greater or equal to 0.5 then the variable is feasible to be tested and can be continued to the next stage. The KMO value obtained from the studied variable is 0.885 . The $\mathrm{KMO}$ value obtained is greater than 0.5 , so factor analysis is feasible to be used in this study.

The next step is to look at the matrics anti-image table. In the anti-image matrics table there is an anti-image correlation column which can show the MSA value in the form of a number that forms diagonally. MSA value must be greater than 0.5. If a variable has an MSA value below 0.5 then that variable must be eliminated. For the variables tested, the MSA values for all variables above 0.5 so that it can proceed to the next stage.

Then in the next stage communalities values are generated through extraction with the Principal Component Analysis (PCA) method. The PCA method also produces Total Variance Explained which shows the value of Eigenvalues. Eigenvalues of more than 1 indicate that each factor is able to represent the variables analyzed which are indicated by the magnitude of the variance described. In the extraction process using the PCA method, there are 4 new factors that have more than 1 Eigenvalues.

Table 3. New Factors and Variable Loading Factors

\begin{tabular}{|c|c|c|c|c|}
\hline No & $\begin{array}{l}\text { New } \\
\text { Factors }\end{array}$ & $\begin{array}{l}\text { Percentage } \\
\text { Of Variance }\end{array}$ & Variabel & $\begin{array}{c}\text { Loading } \\
\text { Factor }\end{array}$ \\
\hline \multirow[t]{11}{*}{1} & \multirow[t]{11}{*}{ Information } & \multirow[t]{11}{*}{46,52} & Financial Statement Information & .829 \\
\hline & & & Business Prospects & .790 \\
\hline & & & Daily Stock Movement Charts & .770 \\
\hline & & & Right Issue & .748 \\
\hline & & & Buyback & .712 \\
\hline & & & Performance of The Company & .703 \\
\hline & & & Stock Analysts & .688 \\
\hline & & & GMS & .654 \\
\hline & & & Devidend Distributin & .622 \\
\hline & & & Stock Split & .594 \\
\hline & & & Pay Dividend & .564 \\
\hline \multirow[t]{4}{*}{2} & \multirow{4}{*}{$\begin{array}{l}\text { Preferred } \\
\text { Stock }\end{array}$} & \multirow[t]{4}{*}{9,56} & Area Resistent & .792 \\
\hline & & & Area Support & .735 \\
\hline & & & Bluechip Stock & .712 \\
\hline & & & Fried Stock & .608 \\
\hline \multirow[t]{4}{*}{3} & \multirow{4}{*}{$\begin{array}{l}\text { Market } \\
\text { Activiy }\end{array}$} & \multirow[t]{4}{*}{7,63} & Net Foreign Sell & .823 \\
\hline & & & Good Rumors & .774 \\
\hline & & & Net Foreign Buy & .732 \\
\hline & & & Bad Rumors & .659 \\
\hline \multirow[t]{2}{*}{4} & Risk & \multirow[t]{2}{*}{5,76} & Loss Risk $-2 \%$ All & .783 \\
\hline & Limitation & & Loss Risk $-8 \% /$ emiten & .696 \\
\hline
\end{tabular}




\section{First Factor (Information)}

The first factor formed from factor analysis is named information that has eleven variables, namely financial statement variables, stock price charts, issuer's performance, issuer's prospects, stock analysts, announcements and dividend distribution, right issues, buy backs, stock splits and GMS. This factor is the biggest factor formed from the analysis of factors that have a data diversity of 46.52 percent, which means that the decision making process in choosing stocks to buy and or sell takes into account internal and external information factors of 46.52 percent and is the most important factor to be considered in choosing shares on the IDX. The factor loading values for the variables in the information factor are in the range 0.829 to 0.564 .

The information factor therein is the financial statement variable which has the highest loading factor, which is 0.829 , which indicates that before investors make a purchase or sale of shares, the main financial statement information is seen to determine the decision whether the issuer's shares are worth buying or selling, when the company's financial statements issued will influence the decision making process of investors in buying and selling shares on the IDX. The financial statements reflect the company's performance in quarterly or quarterly periods over three months. A healthy and profitable financial report certainly attracts investors to buy the issuer's shares and vice versa, if based on the financial statements the issuer suffers losses and has a lot of debt the investor will deal with the issuer's shares.

Furthermore, there is a business prospect variable which has the second biggest loading factor, namely 0.790 , future business prospects of listed companies are considered because the better the prospects of the company in the future, the more attractive the investor's interest to invest in these shares and causes the stock price to increase and vice versa .Variabel grafik pergerakan harian saham dengan loading faktor sebesar 0,770 .

Daily stock movement charts can reflect and predict stock price movements on the next trading day. This daily stock movement chart will be analyzed by technical analysis. The simplest technical analysis is to determine the area of support and resistance of the stock. Variable chart daily movement of shares can influence the decision making process of investors in buying and selling shares on the Stock Exchange.

The right issue variable with a loading factor of 0.748 , is a policy to increase the outstanding shares in the public by the company. This policy is carried out by the issuer as one way to get cash. The funds from the rights issue can be used by issuers for market expansion and to pay debts. Share prices will rise and influence investors to buy when it is published that right issue funds will be used for market expansion and other positive company activities, otherwise the rights issue will fail to attract investors if it turns out that the funds are only used to pay company debts.

The stock buy back variable has a loading factor of 0.712 which indicates that this variable greatly influences investors' decision making in buying and selling shares on the IDX. Buy back shares are repurchases of shares outstanding in the public by the company. The implication of this policy is that stock prices will rise to a certain price limit offered by the company. Investors who participate when there is this policy are generally the type of shortterm traders because the buy back moment occurs in a relatively short time.

The variable performance of the company or company operations with a loading factor of 0.703. The company's operations also take into consideration investors in buying and selling shares on the Stock Exchange, because by knowing the operational activities and products or services offered by the company running well, investors expect the company to obtain sales profits which will then be distributed to investors in the form of dividends. 
The stock analyst recommendation variable has a loading factor of 0.688 which means that this variable influences the investor's decision making process in buying and selling shares on the IDX. Stock analysts usually provide recommendations on what stocks are interesting to buy or sell every morning before the trading floor opens. Stock analysts are either paid or free from securities. Not a few investors who use stock analysts as a guide in buying and selling shares on the Stock Exchange, especially novice investors.

The GMS variable has a loading factor of 0.654 which means that this variable influences the investor's decision making process in buying and selling shares on the IDX. When there is a RUPS or general meeting of shareholders, it will influence investors to accumulate the shares of the issuer, because after the RUPS there is usually no dividend distribution to shareholders. In addition there is a motive for investors who buy shares when a RUPS will be held is to get the opportunity to attend the GSM that has been scheduled and know the policies and actions that have been and will be carried out by the company in the future.

Dividend distribution variable with transaction at cum date and ex date with loading factor of 0.622 and issuer variable that distributed dividend with loading factor of 0.564 . Dividends are yields given to each shareholder in question. To obtain dividend rights, investors must be registered as shareholders at the cum date or accumulation date and ex date or exit date. At the time before the cum date stock prices will usually surge because many investors buy the shares and go down when ex date is caused by retail investors who directly sell their shares because they only target the recording date of dividend recipients in addition to that companies that routinely distribute dividends also attract investors in long term investment.

The last variable is a stock split with a loading factor of 0.594 . Stock split is the breakdown of the number of shares into a number of more shares by using a lower nominal value per share proportionally, this causes investors to buy shares at a cheaper price. Issuers that carry out stock split stocks usually price per share is included in the expensive category that affects the liquidity of these shares.

\section{Second Factor (Preferred Stock)}

The second factor that is formed from the factor analysis is named preferred stock which has four variables namely the area resistant variable, area support, bluchip stock and fried stock. This factor has a diversity of data of 9.56 percent, which means that the decision making process of investors in buying shares on the Stock Exchange considers the preferred stock factor of 9.56 percent. The loading factor of the variable diversity of yield factor is in the range of 0.792 to 0.608 .

The resistant area variable or price is in the Resistant Area with a loading factor of 0.792 . When the stock price is in the resistant area there are two possibilities that will occur namely, if the price can break resistant and make a new high price (break out new high) then investors will tend to buy this stock and continue to accelerate the stock price increase, but if the price fails to penetrate area resistant investors will sell their shares in order to secure the profits they have earned and cause the stock price to go down quickly.

The second variable included in the factor of choice is the price in the support area with a loading factor of 0.735 . When the stock price is in the support area there are two possibilities that will occur namely, if the price breaks the support, investors will tend to sell their shares because the price will tend to continue to fall and form new support, but if the price fails to penetrate the support area and turn around investors will buy these shares because it is likely that prices will rise within a period of time. 
The next variable in the preferred stock factor is bluechip stock with a loading factor of 0.712. Bluechip shares are shares that are classified as large capitalized stock issuers listed on the IDX. These stock issuers are generally the market leaders in the businesses they run. Bluechip shares attract investors to buy and sell shares because the shares of this company are classified as safe and low risk to invest for a long time.

The last variable on the preferred stock factor is often to buy fried foods with a loading factor of 0.608 . Fried stock is a type of stock that at the time of purchase will provide a loss in the short term, but not long after this type of stock can turn up and provide benefits with a pretty good return value. Fried stocks have illiquid movements and are easily manipulated because of their low prices, so that their movements are easy to go up and down. It will be difficult for novice investors with not much information, fried stock might cause more harm than profit. Stock prices can fall very sharply to near the limit of suspensions, but can go up again to the upper limit of stock suspensions. Therefore, it requires a lot of courage and guts for investors who want to play in this type of stock and suitable for investors who like risk in stock investments.

\section{Third Factor (Market Activity)}

The third factor formed from factor analysis is named market activity which has four variables, namely Net Foreign Sell, good rumors, Net Foreign Buy, and bad rumors. This factor has a diversity of data of 7.63 percent, meaning that the decision making process of investors in choosing stocks to buy and or sell takes into account the market activity factor of 7.63 percent. The factor loading value of the variables in the market activity factor is in the range 0.823 to 0.659 .

Market activity factor there is a Net Foreign Sell variable which has the highest loading factor of 0.823 which indicates that when a foreign investor conducts sales activity on a stock issuer, it will psychologically influence the stock investor to sell his shares to the issuer.

The second variable on the market activity factor is buying when there are good rumors with a leading factor of 0.774 . Good rumors usually make the stock price go up in a short time because it attracts investors to take part in accumulating the issuer's shares until finally the official news is published.

The next variable is Net Foreign Buy which has a loading factor that is equal to 0.732 . Contrary to net foreign sell when there is a surge in volume on a stock caused by net foreign buy, then usually local investors also accumulate these shares.

The last variable is selling when there are bad rumors with a loading factor of 0.659 . The investor's decision to sell his shares when bad rumors circulate is one risk management to reduce losses if the rumor turns out to be true.

\section{Fourth Factor (Risk Limitation)}

The fourth factor that is formed from the factor analysis is named risk limitation which has two variables namely the maximum stop loss tolerance variable $-8 \%$ of trading per share issuer and the maximum risk of loss $-2 \%$ of the total investment capital. This factor has a diversity of data of 5.76 percent which means that the decision making process of investors in buying shares on the Stock Exchange considers a risk limitation factor of 5.76 percent. The loading value of the variable diversity of risk limiting factors is in the range of 0.783 to 0.696 .

The first variable in the risk limiting factor is the maximum stop loss tolerance variable $8 \%$ of trading per share issuer that has a loading factor of 0.696 . This variable influences the decision making process of investors in buying and selling shares on the IDX, investors will tend to consider stop loss or sell their shares if the stock falls from the purchase price of $-8 \%$, 
the figure depends on the money management of each investor there is less than $-8 \%$ already stop loss there is also more than $-8 \%$.

The next variable is the maximum risk of loss of $-2 \%$ of the total investment capital with a loading factor of 0.783 . These results indicate that investors will consider and evaluate the performance of their shares if they reach a risk of maximum loss of $-2 \%$ of the total investment capital.

\section{Conclusions and Suggestions}

\subsection{Conclusions}

Based on the results of research that has been done, it can be concluded as follows:

1) Stock investor respondents on the Stock Exchange numbered 316 people, dominated by male sex investors with a percentage of 50.9 percent, 87 percent of respondents aged 17 to 25 years, then the most dominant last education was SMA / SMK 85.1 percent as well as employment are students with the same percentage, and as many as 49.7 percent of respondents have invested shares in the IDX for less than 1 year.

2) Test the validity of all statement items in the range of values $0.437-0.803$ above $r$ Table of 0.1104 so that all statement items in this study are valid. Reliability test by looking at the Cronbach's alpha value of 0.940 which is greater than 0.6 then the statement in this study was declared reliable.

3) The decision making process of stock investors to choose shares on the IDX is divided into five stages. At the introduction of needs, the motivation that drives investors to invest in shares is as a source of income with the benefit of getting capital gains and dividends. In the information search stage, sources of information about listed companies are obtained from information searches on the internet with information searching time of around 1-2 days. The next stage is an alternative evaluation that investors consider in choosing stocks because of the potential profit and almost 100 percent of investors have no investment choice other than stock investment. In the decision process stage, all investors plan in advance to buy shares and the biggest influence giver is themselves then the time needed to determine investment choices is 2-7 days. In the post-decision stage, the time experienced in obtaining profit ranges from 3-4 weeks, so the level of satisfaction felt by investors after investing is satisfied and will advise others to invest in shares on the IDX.

4) There are four factors that influence the decision making of stock investors in choosing shares on the Stock Exchange, namely 46.52 percent information factor, 9.56 percent preferred stock factor, 7.63 percent market activity factor and 5 risk limiting factors , 76 percent.

\subsection{Suggestions}

Based on the conclusions obtained, the suggestions made are as follows:

1) Investors must make it a habit to make a summary of the information obtained, in order to arrange trading plans and make money management so that the profits obtained are consistent. Investors should keep a record of every transaction that has been done to evaluate the performance of their stock portfolio in a period, for example, on weekends or at the end of the month. 
2) Respondents in this study are dominant students as status, so it is recommended to conduct stock transactions with investment type not swing trader or scalper because based on the research results, factors that influence investors to buy and sell shares are information, so it takes more time and experience in studying information to get the right decision in investing.

3) It is hoped that further researchers will add to factors other than those examined in this study, such as macroeconomic, microeconomic, and political factors in order to supplement this research in influencing stock purchase decisions on the IDX.

\section{References}

[1] Widianto A. Inflasi Indonesia 10 Tahun. Bola Salju. https://bolasalju.com/artikel/inflasiindonesia-10tahun (2017)

[2] Haming M, Basalamah S. Studi Kelayakan Investasi. Jakarta: Bumi Aksara (2010).

[3] Cholidia R. Perilaku Investor dalam Pengambilan Keputusan Investasi di Pasar Modal (Study Kasus pada Investor Individu di Bandar Lampung). Lampung (ID) : Universitas Lampung (2017).

[4] Tandio, T. \& Widanaputra, A. A. G. P. Pengaruh Pelatihan Pasar Modal, Return, Persepsi Risiko, Gender, Dan Kemajuan Teknologi Pada Minat Investasi Mahasiswa. EJurnal Akuntansi Universitas Udayana, Vol.16,3, 2316-2341. (2016).

[5] Samsul, M. Pasar Modal dan Manajemen Portofolio. Jakarta: Erlangga. (2006).

[6] Novi, Rezza Aji Pratama \& Tisyrin Naufalty T. Ayo, Siapa Berani Menabung Saham?.Diunduh pada tanggal 19 Mei 2019 dari http://finansial.bisnis.com/read/20160306/55/525355/ayo-siapa-berani-menabung saham (2016).

[7] Kotler P, Keller KL. Manajemen Pemasaran. Edisi Ketiga Belas Jilid 1. Jakarta (ID): PT Erlangga (2009).

[8] Tandelilin E. Portofolio dan Investasi. Yogyakarta (ID): Kanisius (2010).

[9] Wira D. Psikologi Trading : Aspek Psikologi dalam Investasi dan Trading. Jakarta (ID): Exceed (2017).

[10] Septyanto D. Faktor-Faktor yang Mempengaruhi Investor Individu dalam Pengambilan Keputusan Investasi Sekuritas di BEI (BEI). Jurnal Ekonomi, Volume 4 Nomor 2, November 2013. Jakarta (ID): Universitas Esa Unggul (2013).

[11] Simamora B. Analisis Multivariat Pemasaran. Jakarta (ID): Gramedia (2005).

[12] Sumardy, Silviana M, Harsono. Customer Loyalty Playbook. Jakarta (ID): Upnormals Publishing (2011).

[13] Ghozali I. Aplikasi Analisis Multivariete dengan Program IBM SPSS 23. Ed ke-8. Harto PP, editor. Semarang (ID): Badan Penerbit Undip (2013).

[14] Ali AZ. Pengaruh Emotional Bias Dalam Pengambilan Keputusan Investasi Saham Pada Investor Pemula Di Indonesia. Yogyakarta (ID) : Repository UGM (2016). 